\title{
Spin-off Policy on Islamic Insurance Industry Development in Indonesia: Maslahah Perspective
}

\author{
Agus Waluyo ${ }^{1 *}$ \\ IAIN Salatiga, Indonesia
}

Submitted: 13 July 2020; Accepted: 26 December 2020; Published: 29 December 2020

\begin{abstract}
This study aims to describe the efforts to develop the sharia insurance industry in Indonesia. This study is a literature review supported by data and analysis with sources in the form of books, articles, websites and documents. This study resulted in several findings, including one of the efforts to develop the sharia insurance industry was pursued by the government through a spin-off policy. The spin-off policy normatively and substantially can encourage the growth of Islamic insurance in the country and in accordance with the community expectations in actualizing benefits in order to protect religion, life, descent, reason and property. The sharia insurance spin-off process in Indonesia has not run as expected. To support the acceleration of spin-off policy realization, it must be supported by strengthening regulations and human resources, product innovation, literacy, and expanding access. The implication of this study is that there is still a need to strengthen regulations and human resources so that the sharia insurance spin-off policy program can be realized.
\end{abstract}

Keywords: Islamic insurance, regulation, maslaha, spin-off 


\section{INTRODUCTION}

Studies on Islamic/sharia insurance became popular when Islamic world was interested, in studying in-depth, the actualization of sharia economics concept. The emergence of Islamic insurance in Islam is based on the assumption that conventional insurance contains riba (the payment of interest), maysir (gambling or speculation), gharar (sale of risky assets) (Man, 2017). From the assumption of conventional insurance rejection, DSN-MUI fatwa No. 21/DSNMUI/X/2001 concerning General Islamic Insurance Guidelines states that Islamic insurance is a way to protect and help each other among several people/parties through investments in the form of assets and/or tabarru' which provides a pattern of returning to face certain risks through a contract (agreement) in accordance with sharia.

Islamic sharia insurance in Indonesia is still stagnant compared to sharia banks that have developed quite rapidly along. According to Ramadhani (2015), the development of Islamic insurance industry faces significant challenges due to several factors, including the weakening of world economy, people who have not been educated about insurance, free market that has begun to be implemented, lack of resources about Islamic insurance, and lack of capital.

Based on FSA (Financial Services Authority/Otoritas Jasa keuangan) data in March 2020, Islamic financial market share in Indonesia, including banking and insurance, only reached $8.98 \%$ of Indonesia's total financial assets. The portion for Non-Bank Financial Industry (NBFI), including Islamic insurance, is only 4.34\%. The FSA's National Survey on Financial Literacy and Inclusion, specifically for Islamic insurance, noted the new Islamic insurance literacy rate of $2.51 \%$ and Islamic insurance inclusion of $1.92 \%$. This indicates a huge opportunity to increase the growth of Islamic insurance in Indonesia.

Although the development of Islamic insurance in Indonesia is still not encouraging, previous studies have shown that there are great opportunities for the future. The Islamic insurance industry in Indonesia has very good prospects for growth. Demand for Islamic-based insurance products will continue to increase, especially supported by large population of Indonesia and a fact that Indonesia is the largest Muslim country in the world (Effendi, 2016). However, the industry will also experience big obstacles as the world economy weakens, people have not been educated about insurance, free markets have begun to be implemented, and resources about Islamic insurance and the capital are lacking (Ichsan, 2016). Therefore, the government should play a role to help them continue to grow with regulations that support this industry.

According to Effendi (2016), in addition to the need of support from professional and adequate human resources, capital support, and regulations as a legal umbrella, more serious and comprehensive socialization by synergizing the interests of various parties such as the 
insurance industry, government, Islamic scholars, academics, and institutions that focus on the development of sharia business is needed.

The strategic role of Islamic insurance industry in people economic development must always be improved by capturing various opportunities in the digital financial era by using technology in insurance products. This competition is further strengthened by the enforcement of ASEAN Economic Community (AEC) in 2016 for the insurance industry, which became an opportunity as well as a challenge for Islamic insurance industry in Indonesia (Hidayat, 2018).

This industry must continue to strengthen itself to increase its role in developing the economy in Indonesia. The Islamic insurance industry, which is Muslim community awareness of sharia concepts application in economy, should be able to play a major role in insurance industry. Given that, most of population in Indonesia is Muslim. Another important thing to support the development of Islamic insurance industry in Indonesia is to take advantage of economic growth opportunities. By taking advantage of these opportunities, the Islamic insurance industry in Indonesia can develop and be competitive (Jannah \& Nugroho, 2019).

According to Galal and Kabbashi (2017), the Islamic insurance industry in the world is experiencing a rapid growth trend in terms of contribution and profit, although it still faces obstacles in several aspects. In Indonesia, the growth of the sharia insurance industry is still below the growth of conventional insurance (Mutawali, 2016). Due to these conditions, the government has issued a spin-off policy as regulated in Law Number 40 of 2014 Article 87 concerning Insurance, therefore, to carry out the law mandate, the Financial Services Authority has issued Regulation number 67/ POJK.05/2016.

According to FSA data, from 2014 to 2019 there were only four Sharia Business Units (UUS) in conventional insurance companies that separated from the parent company, namely Jasindo Syariah and Askrida Syariah from general insurance and Asuransi Jaya Proteksi (AJP) Syariah and ReINDO Syariah from life insurance. Meanwhile, 94 other UUSs are still preparing to spin off before the end of the 2024 deadline. In general, Islamic business units are not ready to spin off with their parent companies (Ramadhani, 2015).

The spin-off policy to encourage the development of Islamic insurance did not receive a positive response. This paper aims to examine further the efforts to develop Islamic insurance in Indonesia. This study will also describe the values of falsehood in the sharia insurance spinoff policy. Among the studies related to the sharia insurance industry and opportunities for development have been carried out, among others, by Firdaus and Prianto (2013), Ramadhani (2015), Ichsan (2016), Effendi (2016), and Nizar (2018). Other studies were conducted by Bakhtiar, Munir, and Al-Qasas (2018), Dasopang (2019), and Nasution (2019). These studies have not focused on examining the spin-off policy in supporting the development of sharia insurance as well as the benefit values in the policy. 


\section{METHOD}

This study is a library research using qualitative techniques. Library studies are carried out using literature, both in the form of academic journals, books, documentation, notes, and previous research results. As a qualitative study, it is carried out through the stages of data collection, processing and analysis. The data used is in the form of secondary data which is considered relevant to this study. The data obtained were analyzed using a descriptive analysis method. Descriptive analysis is carried out by compiling the data obtained then analyzed and interpreted by doing data reduction, data presentation and analysis so that some conclusions can be drawn. The data analysis uses theories and concepts in accordance with the research focus, namely the concept of Islamic insurance, maslaha, spin-off policies, and development strategies

\section{RESULT AND DISCUSSION}

\section{Islamic Insurance and Economic Growth}

Islamic insurance is a non-bank financial institution that runs its operational principles in accordance with Islamic law. According to Bappenas (2018), sharia insurance is a shariabased social security scheme operated by private companies, in addition to sharia-based pension funds. Since 2015, the development of sharia insurance in Indonesia has shown an upward trend in terms of assets, although growth has slowed down. The slowdown in growth has started in 2017 with asset growth of 21.89 percent from the previous year. According to FSA data in the Sharia IKNB Statistics, in August 2018 sharia insurance has total assets of IDR 41.68 trillion, with details of IDR 34.35 trillion in general insurance, IDR 5.48 trillion in life insurance, and IDR 1.85 trillion in reinsurance (Bappenas, 2018). The Islamic insurance industry in Indonesia is experiencing varying growth in accordance with national economic growth. In line with the positive growth in Islamic insurance assets, the contribution of this sector to the Gross Domestic Product (GDP) is constantly increasing from 2014 to 2018. From 2014 to 2017, the contribution of Islamic insurance was still below 1\%, but it increased by $1.13 \%$ in 2018 . If it continues to be developed by further identifying the challenges and opportunities, the Islamic insurance sector will have a big potential to be developed and to accelerate growth and increase its contribution to Indonesia's GDP(Bappenas, 2018).

The Islamic insurance industry can contribute to transform the economy into productive, value-added, and inclusive economic activities. Islamic insurance provides a major contribution to regional economic growth by helping to form capital. Capital is formed through compensation for those affected by disasters or through investment, where companies make large financial investments in many projects that realize recovery efforts for the regional 
economy. Also, Islamic insurance can reduce the unemployment rate by providing employment opportunities. Therefore, the growth of Islamic insurance will have an impact on economic growth, marked by an increase in the Gross Domestic Product indicator. Even Islamic insurance with its various products will be a sharia-based investment solution. The growth of Islamic insurance will promote a healthy investment climate and support the Indonesian economy (Mainata \& Pratiwi, 2019).

\section{Support for Islamic insurance Spin-off Policy Implementation}

The spin-off policy is generally regulated in the explanation of Law Number 40 of 2007 concerning Limited Liability Companies. Spin-offs are a way of restructuring a company that is able to operate efficiently and effectively to compete with other companies, both nationally and internationally. The general definition of a company spin-off is described in Article 1 Number 12 Article 135 of the Limited Liability Company Law of 2007. Spin-off is defined as a legal action taken by the Company to separate the business which results in all assets and liabilities of the Company being transferred due to law to 2 (two) companies or more or some of the assets and liabilities of the Company are transferred by law to 1 (one) or more Companies.

Specifically regarding the sharia insurance spin-off is regulated in Law Number 40 of 2014. Article 87 paragraph 1 states that sharia business units in insurance companies and reinsurance companies are required to spin-off if tabarru' funds and participant investment funds have reached at least $50 \%$ (fifty percent) of the insurance funds total value, tabarru' funds, and participant investment funds in their parent company or 10 (ten) years since the enactment of the law.

Many parties and groups should make serious efforts to develop Islamic insurance as a major part of sharia-based social security institutions in Indonesia. To support the sustainability of spin-off policy, it is necessary to strengthen regulations, public literacy, and increase human resources, even mastery of technology (Wulandari, Siregar, \& Tanjung, 2019).

\section{Strengthening Regulation}

Specific regulations of insurance business using sharia principles have only been legalized through PMK Number 18/PMK.010/2010 concerning Implementation of Basic Principles for Running Insurance and Reinsurance Business with Sharia Principles. This regulation was made to comply with sharia principles and legal certainty in the operation of insurance and reinsurance business with sharia principles (Mutawali, 2016). 
Islamic insurance regulations in Indonesia are marked by several Minister of Finance Regulations on Islamic Insurance, including, (a) Minister of Finance Decree Number 426/KMK.06/2003 concerning Business Licenses and Institutions of Insurance and Reinsurance Companies, (b) Minister of Finance Decree Number 424/KMK.06/2003 concerning Financial Health of Insurance and Reinsurance Companies, and (c) Director General of Financial Institutions Decision Number Kep.4499/LK/2003 concerning Types, Investment Assessment and Limitation of Insurance and Reinsurance Companies with Sharia Systems. With the issuance of Law No. 40 of 2014 concerning Insurance, the existence of Indonesian Islamic insurance has a strong legal foundation.

Regulatory readiness is one supporting factor to encourage the development of Islamic insurance in Indonesia because Islamic insurance relies on Islamic principles to be accommodated in statutory regulations. FSA realizes the importance of regulations for every industry, including Islamic insurance to encourage the development of industries in a fast, healthy, and accountable manner (FSA, 2015)

Although the Indonesian Sharia Economic Masterplan has been prepared for 2019-2024 (Bappenas, 2018) and FSA has issued Regulation number 67/POJK.05/2016 as an effort to speed up the spin-off process, FSA needs to make regulations to encourage Islamic insurance to resolve the problems in the sector. Islamic insurance business actors ask the government to differentiate between conventional and Islamic/sharia regulations. However, Islamic insurance has several provisions that do not exist in conventional insurance, which is the payment of zakat (alms), so regulators need to distinguish the two kinds of insurance.

One of them is related to the regulation and supervision of mutual insurance, in which, until now, there is only one in Indonesia. During this time, the regulation of Islamic insurance is indeed somewhat late than the conventional one. With regulations, foreign investors will be more interested in investing in Islamic insurance. So far, foreign investors who plan to invest in Islamic insurance are still constrained in terms of regulations regarding foreign ownership.

To improve Islamic insurance, the role of legal policy is needed in the process of regulatory positification to create directions, methods, and policies in formalizing the laws relating to Islamic insurance in Indonesia. Legal policy needs to be carried out by the government by creating regulations as checks and balances by making policies to support Islamic insurance activities, both the institution and system, so that it remains directed. Besides, the government's political will is needed to accelerate the realization of Islamic insurance order as a just economic system and apply sharia principles, thus creating a better atmosphere of economic growth (Irawan, 2018). 


\section{Human Resources Capacity Building}

In addition to the issue of regulation, the readiness of human resources is one of the strategic issues in the development of Islamic financial industry, including Islamic insurance, bearing in mind that these human resources will be the drivers in product innovation, improvement in the quality of company's internal processes and services to participants (FSA, 2015). These strategic issues require support from the government, FSA, and the Islamic Insurance Association of Indonesia (AASI).

Among the problems faced by the Islamic insurance industry for implementation of spinoff policy are inadequate professional human resources and the lack of public knowledge about the importance of insurance for their lives. Therefore, to improve human resources in Islamic insurance institutions, there are several things that must be done, including building professional human resource management, establishing education and training centers, and professional certification for prospective workers and workers in Islamic insurance. These are expected to be able to meet the gap between Islamic and conventional insurance workers, increase the global competitiveness of human resources, and improve the performance of Islamic insurance institutions themselves.

In addition, to improve the quality of human resources in Islamic insurance, some efforts must be made (Agusti, 2019); first, applying the provisions of professional certification standards of Islamic insurance practitioners for Board of Directors, Board of Commissioners, Experts, and Sharia Supervisory Board; second, supporting the cooperation of Islamic insurance with agencies and related parties to create more professional human resources in Islamic insurance.

One step that can be taken to improve human resources is interconnecting cooperation between Islamic insurance practitioners and other parties to establish education and training centers. This training is intended to create experts to meet the gaps that occur. In this case, many parties can play a role, such as Islamic FSA, National Sharia Board of Indonesian Ulema Council, Indonesian Association of Islamic Economists (IAEI), Islamic Economy Society (MES), and educational institutions who have Islamic economics and finance majors and expertise. During the training, the role of higher education dominates because lecturers with their teaching and evaluation methods used in the teaching process play a significant role in supporting students' knowledge and understanding of Islamic economics and finance, including Islamic insurance. The interconnection is expected to be able to train the human resources they have and identify the types of expertise needed by the Islamic insurance industry. 
Besides training, certification is also important in the human resource management process. Certification becomes even more important when faced with global competition. Without certification, it is difficult to prove one's expertise in their field, which will cause them to have difficulty competing with others who already have certificates of expertise. For Islamic insurance institutions, certification is essential because many human resources today have competence in financial management and insurance but do not understand Islamic laws. On the other hand, many understand Islamic laws but cannot manage finance and insurance. Therefore, it is not surprising if, until now, it is still difficult for Islamic insurance to compete with conventional insurance.

In contrast to training, certification should be done to prospective workers in Islamic insurance so that all Islamic insurance workers have good qualifications to improve the performance and quality of the insurance institution itself. However, the certification cannot be carried out without interconnection among the stakeholders of Islamic insurance. In this case, the National Professional Certification Board (BNSP) has a very strategic role. BNSP is expected to be an institution that can increase human resources of Islamic insurance.

The existing human resources in Islamic insurance companies are required to understand the principles of sharia well, as well as the brokers, marketing, and agents, who work with Islamic insurance companies. Sharia certification for brokers who work with Islamic insurance must be done due to the high demand of market. Islamic insurance companies are expected to prioritize absorbing the workforce of university graduates who have been educated and are ready to enter the business (Saharuddin, 2014).

\section{Product Innovation}

Several Islamic insurance products cover various aspects of life, ranging from protection against accidents that result in death to the occurrence of fires and accidents in transportation. The products are classified into saving and non-saving insurance products. Saving insurance products include investment funds, student funds, pilgrimage funds, and hasanah funds while non-saving products include individual health, personal accident, and individual al-khirat (Sula, 2004).

The Islamic insurance industry is to increase product innovation more, to increase inclusion, support growth, and explore the potential of various sectors that have not been served. Opportunities for innovation in the form of the presence of products that are in line with the religious concept and values that can be accepted by the wider community and the concept of Islamic insurance that can improve justice so that people choose Islamic insurance as a partner in business and insurance needs (Al-Arif, 2015). 
Islamic insurance products currently still need to be developed by providing a variety of products and services with a more varied financial scheme. This is an innovation in Islamic insurance products. Product innovations can be repackaged or new products. Islamic insurance product innovation is a requirement to follow the trend to become a strong industry and a choice for the community. Islamic insurance product innovation must be in accordance with the policy direction set by FSA. In conducting product innovation, the Islamic insurance industry must be able to take advantage of technological development opportunities by providing ICT-based products so that it is more attractive to the public. Product innovations carried out by Islamic insurance should pay attention to economic and social dimensions. From the economic aspect, the innovation of Islamic insurance products must be in line with the needs of customers while still complying with Islamic rules. Thus, product innovation can produce more varied insurance products. From the social aspect, Islamic insurance must educate the public through product innovation.

\section{Expansion of Access}

The community, who have a high enough awareness of the importance of insurance, plays an important role in the success of existing Islamic insurance companies. Nowadays, the Islamic insurance industry is not the first choice. Until now, business actors who run the Islamic insurance industry, in general, are still driven by those who were originally conventional insurance practitioners. One of the orientations is to drive Islamic insurance due to the high profit that will be generated. The government is expected to give more portion to this industry or introduce Islamic insurance more to the public. Inequality of access to Islamic insurance between urban and rural areas results in a low level of inclusion and literacy in Islamic finance. Public understanding and awareness of Islamic insurance are still minimal so that information dissemination about the products, systems, uses, and benefits of Islamic insurance to the public is needed (Jannah \& Nugroho, 2019).

To expand public access to Islamic insurance products in order to realize increased penetration and inclusion of Islamic insurance in Indonesia, product development efforts are needed. This product development strategy is very important to maintain the company existence. For the products produced by Islamic insurance to be in demand, it is necessary to promote the products and the benefits, their advantages, and characteristics compared to other products. Islamic insurance must strive to promote all its products and services both directly and indirectly to customers. The main purpose of promotional activities is to inform and communicate to the public about the existence of products, benefits, advantages, attributes, and how to get them. 
Islamic insurance must have easy access related to the availability of financial services and information spread throughout Indonesia. In addition, Islamic insurance is also demanded to increase the Islamic financial literacy of the community through several programs. To increase public financial literacy, Islamic insurance must refer to the principles of inclusiveness, systematicness and measurably, easy access, and collaboration.

\section{Islamic Insurance Spin-off Policy on Maslaha Perspective}

According to Kuncoro and Yulianto (2018), spin-off will be able to increase employment and healthy economic growth, increase company innovation and entrepreneurial potential, long-term economic growth, provide benefits to the parent company, increase regional competitiveness, and create a dynamic environment. Spin-off will be able to have a positive impact because of the interaction between technology, entrepreneurship, and industrial clusters in different economic areas.

The spin-off is a form of insurance industry's commitment to develop the expansion of sharia industry to make it more effective and efficient. The sharia unit spin-off will have an impact on increasing the share of sharia insurance market (Nasution, 2019). FSA places serious emphasis on the sharia unit to prepare and carry out a spin-off by improving and maximizing the performance and preparing components such as adequate human resources, strong assets, complete infrastructure, and supportive management.

Islamic insurance was made from the spirit of Islamic values to preserve sharia principles, namely responsibility (QS. Ali-Imran: 103), working together to help each other (QS. Al-Maidah: 2, Al-Baqarah: 177), protecting each other in every situation (QS. Quraysh: 4, Al-Baqarah: 126), and avoiding practices that deviate from Islamic teachings, such as riba, maysir, and gharar. The approach of Islamic insurance refers to the values in Al-Qur'an and Hadith as a basic guideline in running each of the activities. Thus, conceptually, Islamic insurance is based on the provisions of Al-Qur'an and Hadith. Operationally, Islamic insurance contains the value of mutual help and is not solely profit oriented (Zaini, 2015). The operational principle of Islamic insurance is to create welfare (falah) and comfort against risks with the principle of mutual help in good (tabarru') to get mutual benefits.

In maslaha perspective, the existence of Islamic insurance is a tool to eliminate business practices that are prohibited in Islam, such as gambling, gharar, fraud, and usury. The existence will be able to support the realization of establishing sharia (maqashid syariah) purpose in order to protect human interests such as protection of religion, soul, mind, descent, and property. Therefore, it cannot be denied that sharia unit spin-off on Islamic insurance will have an impact on the realization of human benefit. Problems are a basic principle of maqasid sharia (Ghulam, 2016). 
The main purpose of Islamic law is for the good of all human beings called Maqasid alsyari'ah (Auda, 2008). Maqasid al-syari'ah consists of two words, maqāsid and syari'ah. Maqashid means intent or purpose. Maqshad and maqashid are derived from the root word qashd. Maqashid is a word that indicates a plural noun, the mufrad (singular form) is maqshad which means goal or target (Sahroni \& Karim, 2016; Syafei, 2017; Aziz, Sholikhah, Hadi, \& Ghofur, 2019).

Maqasid al-syari'ah is the goal to be achieved behind the making of sharia law for humans to achieve welfare in the world and hereafter by preserving religion, life, intellect, progeny, and wealth. One basic principle of sharia is to support maslahah for everyone in the world and hereafter. In summary, maqashid syariah is defined as the fulfillment of human needs by realizing maslahah (disadvantage) and protecting them from mafsadah (advantage) (Sahroni \& Karim, 2016). To reach maqasid al-Syari'ah, maslahah should be practiced, where the understanding of maslahah is directly related to the command. Thus, it can be concluded that the concept of maslahah is the principle of maqasid al-Syari'ah thought because it generally relies on maslahah (Abubakar \& Sukmadilaga, 2017). Achievement of maslahah is important to achieve the goal of syara'. The concept of maslahah is an important and central theme because there are many contemporary problems, including finance and business, associated with the application of maslahah.. Maqashid syariah and maslahah are analytical tools that can answer issues related to the current sharia economy and business (Setiawan, 2020).

In Islamic insurance, maqashid syariah will provide a rational and substantial thought pattern to existing contracts and products, which will open up considerable opportunities in the development of products that continue to change rapidly according to the demands of times. This approach will be different when compared with mere fiqh thinking, which gives more formalistic and intellectual patterns of thought (Zaki \& Cahya, 2015).

Islamic insurance is considered to have a strong relationship in achieving maqashid syariah, especially in protecting religion, life, religion, progeny, and wealth. In the protection of religion, Islamic insurance can be realized through transactions that begin with contributions in the form of tabarru' (donation). In line with the aim of preserving life, Islamic insurance encourages Muslims to do good deeds for themselves and others by taking preventive measures against risks that can harm themselves (life), such as health or death that is unpredictable.

The practice of Islamic insurance free from the prohibition of syara' and its operations in accordance with sharia will create peace of mind and heart for the participants and administrators of sharia insurance (Abdullah, 2012; Dikko \& Ghani, 2015). Income obtained from Islamic insurance will lead to income and profit that makes peace of mind and heart. 
Sharia indeed protects the descendant as stipulated in maqashid asy-syariah, namely $h i f d z$ an-nasb. This has the same meaning of insurance that is protecting, so the function of insurance is to protect the descendant as protected by sharia. Thus, Islamic/sharia insurance has a function to realize the objectives of maqashid syariah.

As for the protection of assets, it can be seen from the aspects of fund management and the ownership status of funds that are managed well. The existence of insurance products that provide protection for assets/property owned such as loss or damage to property caused by fires, earthquake, flood, or other accidental disasters is one example of Islamic insurance efforts in providing protection for one's assets.

Maslahah is the key principle in muamalah (Renie, Luth, Hamidah, \& Sihabuddin 2019). Therefore, in investments, it needs to ensure that the investments made by investors can provide positive social and environmental impacts on people's lives, for both the current generation and future generation. Islamic insurance is present to realize welfare (falah). Falah can be achieved by fighting for maslahah. Achievement of maslahah must be in line with the objectives of sharia, namely maintaining and preserving religion, life, intellect, progeny, and wealth (Firdaus \& Prianto, 2013). Maqashid syariah is needed to formulate macro and microeconomic policies; it also plays a role in creating Islamic financial products. Besides, maqashid syariah is also very necessary in making regulations on Islamic financial institutions (Abubakar, 2016).

Sarpini (2019) explains that in the concept of mașlahah, insurance experts have talked about the various functions and roles of insurance in society, the objectives to be realized, and the expected benefits (results). These functions can be described in three ways. First, Islamic insurance provides security and peace of mind. Feeling secure is a common need for humans in this modern era because discoveries in science and technology have an impact on the emergence of various risks that threaten their lives. Second, Islamic insurance provides a useful installment facility or capital support that makes a person enjoy the assets obtained to facilitate his work. Third, Islamic insurance is one of the saving facilities.

\section{CONCLUSION}

The government requires sharia insurance spin-off with the aim of increasing business capacity and increasing the entity through corporate independence. The spin-off policy is seen as being able to have a positive impact on the development of the sharia insurance industry in Indonesia for the creation of independent Islamic insurance. Independent sharia insurance will be more flexible in developing the business expansion and encouraging it to be more competitive. In fact, the sharia unit spin-off policy on sharia insurance is still experiencing 
crucial obstacles and has not received a positive response. The government's spirit through the spin-off policy has not been in harmony with reality.

Efforts to support the sharia unit spin-off policy in sharia insurance include strengthening regulations, strengthening human resources, product innovation, and expanding access. With this support, it is hoped that sharia insurance can immediately spin-off from conventional insurance as the parent. Some schemes that can be taken to spin-off sharia units include the establishment of sharia insurance from the separation of sharia units, transferring to licensed sharia insurance companies, or return the sharia license to FSA. With the acceleration of spin-off, it will further foster public confidence in Islamic insurance, whose operational system is in accordance with the guidance of religion (Islam) and aims for the benefit and welfare of humans.

\section{BIBLIOGRAPHY}

Abdullah, S. (2012). Risk Management via Takaful from a Perspective of Maqasid of Shariah. Procedia-Social and Behavioral Sciences, 65(ICIBSoS), 535-541.

Abubakar, L. \& Sukmadilaga, C. (2017). Implementasi Kepatuhan Terhadap Prinsip Syariah Melalui Penggunaan Polis Standar dalam Asuransi Syariah. Rechtidee, 12(1), 107-133. DOI: https://doi.org/10.21107/ri.v12i1.2852.

Abubakar, Y. S. (2016). Corporate Social Responsibility of Islamic Financial Institutions: A Look from the MaqasidA1-Shariah (Purpose of Shariah)Approach.Business and Economics Journal, 7(4), 4-7. DOI: 10.4172/2151-6219.1000255.

Agusti, N. (2019). Relevansi Asuransi Syari'ah dengan Konsep Maqashid Syari'ah: Telaah Indikator. Saqifah: Jurnal Hukum Ekonomi Syari'ah, 4(1), 65-74.

Al-Arif, M. N. R. (2015).Pemasaran StrategikPadaAsuransi Syariah. Bekasi: Gramata Publishing.

Auda, J. (2008). Maqasid Asy-Syariah as Philosophy of Islamic Law: A Systems Approach, London: IIIT.

Aziz, M., Sholikhah, Hadi,A., \& Ghofur, A. (2019). Reconstruction of Maqashid Shari'ah Perspective Muhammad Thahir Ibn 'Assyria: Efforts to Re-Discuss Sharia with Reality. Jurnal Hukum Islam, 17(2), 231-249. DOI: https://doi.org/10.28918/jhi.v17i2.2396.

Bakhtiar, F., Munir, M., \&Al Qasas, A. (2018). Deteksi Kebangkrutan pada Industri Asuransi Syariah di Indonesia. Ihtifaz: Journal of Islamic Economics, Finance, and Banking, 1(1\&2), 123-136. DOI: https://doi.org/10.12928/ijiefb.v1i1.286.

Bappenas. (2018). Masterplan Ekonomi Syariah Indonesia 2019-2024. Jakarta: Kementerian Perencanaan Pembangunan Nasional. 
Dasopang, N. (2019). Tinjauan Hukum Pemisahan (Spin Off) Unit Usaha Syariah Menjadi Perusahaan Asuransi Syariah (Full Fledge). Yurisprudentia: Jurnal Hukum Ekonomi, 5(1). DOI: https://doi.org/10.24952/yurisprudentia.v5i1.1673.

Dikko, M. \& Ghani,A. B. H. A. (2015). MaqasidA1 Sharia and Takaful Operations: Issues and Challenges in an Emerging Industry. Journal of Law, Policy and \& Globalization, 43, 30 33.

Effendi, A. (2016). Asuransi Syariah di Indonesia (Studi Tentang Peluang ke Depan Industri Asuransi Syariah). Wahana Akademika,3(2), 71-92. DOI : 10.21580/wa.v3i2.1145.

FSA(Financial Service Authority/Otoritas Jasa Keuangan). (2015). Roadmap Perbankan Syariah Indonesia 2015-2019. Jakarta.

Firdaus, A. \& Prianto, E. (2013). Pengukuran Kinerja Bisnis Berbasis Syariah dengan Maslahah Scorecard. Review of Islamic Economics, Finance, and Banking, 1(2), 233-252.

Galal, F. A., \& Kabbashi, N. A. (2017). Islamic Insurance in the Global Economy. International Journal of Business and Management Invention, 6(6), 8-10.

Ghulam,Z.(2016). Implementasi Maqashid Syariah dalam Koperasi Syariah. Iqtishoduna: Jurnal Ekonomi Islam, 5(1).90-112.

Hidayat, Y.R. (2018). Analisis Peluang dan Tantangan Lembaga Keuangan Syariah Untuk Meningkatkan Daya Saing Menghadapi Masyarakat Ekonomi ASEAN. Amwaluna:Jurnal Ekonomi dan Keuangan Syariah, 2(2), 165-181. DOI: https://doi.org/10.29313/amwaluna. v2i2.3755.

Ichsan, N. (2016). Peluang dan Tantangan Inovasi Produk Asuransi Umum Syariah. Jurnal Ekonomi Islam, 7(2), 131-156.

Irawan, M. (2018). Politik Hukum Ekonomi Syariah dalam Perkembangan Lembaga Keuangan Syariah di Indonesia. Jurnal Media Hukum, 25(1), 10-21. DOI: https:/doi.org/10.18196/ jmh.2018.0097.10-21.

Jannah, D. M. \& Nugroho, L. (2019). Strategi Meningkatkan Eksistensi Asuransi Syariah di Indonesia. Jurnal Maneksi (Management, Ekonomi, dan Akuntansi), 8(1), 169-176. DOI: https://doi.org/10.31959/jm.v8i1.235.

Kuncoro, A., \& Yulianto, H. (2018). Kinerja Keuangan Sesudah dan Sebelum Spin Off Unit Usaha Syariah ke Bank Umum Syariah. Equilibrium: Jurnal Ekonomi Syariah, 6(2), 291-315. DOI: 10.21043/equilibrium.v6i2.4784.

Mainata, D., \& Pratiwi, A. (2019).PengaruhPertumbuhan Asuransi Syariah terhadap Pertumbuhan Ekonomi Indonesia. International Journal Ihya' 'Ulum al Din, 21(1), 56-79. DOI: http: //dx.doi.org/10.21580/ihya.21.1.4162. 
Man, Y. L. (2017). Aktualisasi Asuransi Syariah di Era Modern. Mizani: Wacana Hukum, Ekonomi dan Keagamaan, 4(1), 77-84. DOI: http://dx.doi.org/10.29300/mzn.v4i1.1012.

Mutawali. (2016). Analisis Kesehatan Keuangan dan Kebangkrutan Kepada Asuransi Bumiputera Syariah. Kreatif: Jurnal Ilmu Prodi Manajemen, 4(1), 190-209 DOI: http://dx.doi.org/ 10.32493/jk.v4i1.y2016.p190.

Nasution, L.Z.(2019). Strategi Spin-Off Bagi Pengembangan Keuangan Syariah:Tinjauan Pada Kasus Asuransi Syariah. Jurnal Dinamika Ekonomi Pembangunan, 2(2), 213-226. DOI: https://doi.org/10.33005/jdep.v2i2.95.

Nizar, M.A. (2018). The Struggling of Sharia Insurance in Indonesia. In Anthology Book Series Disruptive Mindset of Financial Sectors. IPB Press.

Ramadhani, H. (2015). Prospek dan Tantangan Perkembangan Asuransi Syariah di Indonesia. Al Tijary: Jurnal Ekonomi dan Bisnis Islam, 1(1), 57-66. DOI: https://doi.org/10.21093/at. v1i1.422.

Renie, E., Luth, T., Hamidah, S., \& Sihabuddin(2019). The Maslahah Concept in the Islamic Finance Institution. Journal of Law, Policy and \& Globalization, 87, 117-121. DOI: 10.7176/JLPG/87-12.

Saharuddin, D. (2014). Asuransi Syariah dalam Praktik (Studi Analisis terhadap Shariah Compliance). Esensi: Jurnal Bisnis dan Manajemen, 4(3), 123-136. DOI: https://doi.org/10.15408/ess. v4i3.2438.

Sahroni, O. \& Karim, A. A. (2016). Maqashid Bisnis \& Keuangan Islam: Sintesis Fikih dan Ekonomi. Jakarta: Rajawali Pers.

Sarpini. (2019). Tinjauan Maṣlaḥah terhadap Metode Istinbat Fatwa Majelis Ulama Indonesia tentang Asuransi Jiwa. Volksgeist: Jurnal Ilmu Hukum dan Konstitusi, 2(1), 21-37. DOI: 10.24090/VOLKSGEIST.V2I1.1961.

Setiawan, I. (2020). Maqashid Sharia's Criticism of the Pareto Optimum Theory. Muqtasid: Jurnal Ekonomi dan Perbankan Syariah, 11(1), 14-28. DOI : 10.18326/muqtasid.v11i1. 14-28.

Sula, M. S. (2004). Asuransi Syari'ah (Life and General): Konsep dan Sistem Operasional. Jakarta: PT Gema Insani.

Syafei, Z. (2017). Tracing MaqasidAl-Shari 'ah in the Fatwas of Indonesian Council of Ulama (MUI). Journal of Indonesian Islam, 11(1). 99-124, DOI: 10.15642/JIIS.2017.11.1.99 124.

Wulandari, L., Siregar, H., \& Tanjung, H. (2019). Spin off Feasibility Study of Sharia Financing Unit: Study in Adira Finance. Al-Iqtishad: Jurnal Ilmu Ekonomi Syariah, 10(2), 299-312. DOI: 10.15408 /aiq.v10i2.5781. 
Zaini, M. A. (2015). Aspek-Aspek Syariah dalam Asuransi Syariah. Iqtishoduna, 6(2), 54-76.

Zaki, M. \& Cahya, B. T. (2015). Aplikasi Maqasid Asy-Syari'ah pada Sistem Keuangan Syariah. Bisnis: Jurnal Bisnis dan Manajemen Islam, 3(2), 312-327. DOI: http://dx.doi.org/10. 21043/bisnis.v3i2.1497. 